\title{
Globalization and the Trade Union Movement in Nigeria
}

\author{
Alhaji Ahmadu Ibrahim \\ Department Of Sociology, Yobe State University Pmb 1144 Damaturu, Yobe State, Nigeria
}

\begin{abstract}
The penetration of the third world societies and their integration into the organic unity structure of the western capitalism via globalization had the greatest impact upon the working class and its organizationstrade unions. And trade unions are often in contestation with the spirit of capitalism currently globalized. The consequences and challenges for the trade union movement in Nigeria that results from the various strategies that are adopted and applied are analyzed. Evidently, globalization through neo-liberal policies impacted negatively on the working class and its organization; by redefining work, skills obsolescence and deskilling of workers, re-engineering, contracting and sub-contracting and casualization of labour, increased job insecurity and unemployment. Similarly, it has led to pauperization of the working class, withdrawal of social provisioning and commodification of basic services by government, increased cost of living, declined in workers' welfarism, consolidation of inequality and erosion of industrial democracy, with their attendant consequences on the organization of trade unionism in Nigeria. The study concludes that, the challenges for the trade union movement in Nigeria results from the various strategies that are adopted and applied by agents/driving forces of globalization. it is considered imperative for workers to be united in confronting the enormous power of capital. This can be done through the collective effort that required both socio-political and economic responses from the trade union movement in Nigeria.
\end{abstract}

- Globalization

\section{BASIC CONCEPTS}

- Trade union

- Liberalization

- Privatization

- Commercialization

- Deregulation

- Merger

- Strategic alliance

- Ideology

- Debt entrapment

\section{Introduction}

There is now little or no doubt that, in the modern period, globalization represents the most significant development in the World economy and for this reason, its nature and effects have been analyzed for different areas of economic, political and social life. The overall effect is that has been much less discussion of the effects of globalization on distinct social groups, such as trade unions in third World Countries in general, and in Nigeria in particular.

By all accounts and in practical terms, globalization has tended to have the greatest impact upon the Working class and the organization of the working class i.e. 'trade union' in Underdeveloped Societies. A result of this development is that, Workers and Labour Organizations are confronted by evolving regulatory structures and novel production system that have implications for the manner trade unions pursue their goals and conduct their activities. A result of this development is that, labor becomes the first casualty in the process of globalization. As such workers and labor organizations are confronted by evolving regulatory structures and novel production system that have implications for the manner trade unions pursue their goals and conduct their activities. This therefore, informs the choice of the topic tagged Globalization and Trade Union Movement in Nigeria. And as argued by orthodox writers on the subject, trade union is incapacitated due to the erosive powers of globalization and hence, the terminal decline of unions and the "death of unionism" (Kaufman). The study therefore, investigates the impact of globalization on trade union movement in Nigeria with emphasis on the major obstacles to the survival of trade unionism.

In the case of Nigeria like many third World countries, Workers and their trade unions lack adequate understanding of the nature of globalization, the character of its driving forces (institutional agents), the particular strategies that are adopted by these agents, the consequences of the strategies for them and how they 
should deal with them; in short, they lack an understanding of globalization that is not only holistic but that would enable them manage more efficiently the enormous new demands that it creates.

The main objective of the paper is to provide such an understanding from the point of view of the trade union movement in Nigeria. The paper advances the notion of globalization as an expansion of economic practice, which in the modern period is the practice of capitalism. In the process, the paper will discuss the strategies that were appropriated to and therefore deployed in expanding capitalist practice throughout its history. In the modern period, the driving forces i.e. the institutional agents are identified and their deployed strategies in pushing globalization phenomenon are evaluated. Finally, the consequences of these strategies will be analyzed and the responses needed to deal with them by the trade union movement in Nigeria will be forwarded.

\section{Literature Review}

To facilitate this intellectual review, the study will dip into the archaeology of the key conceptual issues under examination.

\section{The Concept Of Trade Union}

Trade unionism is now a universal phenomenon operating in almost every organization-public and private industry, institution, profession, and trade. Product of industrial revolution, it was designed as an instrument mainly to put up a united and collective fight against exploitation of workers by employees in factories. It has since proliferated to all sorts of work place, including office, establishments, banks, educational institutions, et cetera. It was also intended to be used for securing reasonable wage and salaries, favorable conditions of services commensurate with the nature of work, facilities of housing, medical care, education, travel, recreation et cetera.

Trade union has attracted variety of definitions from scholars. Definitions depend on the perception of workers and the definition imposed by legal framework of a particular country. Akpala said (1982) the exact definitions of trade union may vary from one situation to another depending on the economic and political situation encompassing the worker - management relations. According to Sydney and Beatrice Webb (1897), trade Union is a continuous association of wage earners for the purpose of maintaining and improving the condition of their working lives. The Nigerian Labour law Section 1 of Sub section 1 Trade Union Act No 31 of 1973 defines Trade Union as any combination of workers or employers whether temporary or permanent, the purpose of which is to regulate the terms and conditions of employment of workers (Davison, 1977). In the words of Otobo (2000) a trade union is a continuous organization of employees that seeks to maintain and improve the terms and conditions of employment through collective bargaining representation with the employer (from which it remains autonomous) and through other means. Trade labor union can be described as organized grouping of wage and salary earners with the purpose of bringing to bear economic, social and political interest of their members in labour relations.

Another definition is an association of wage or salary earners formed with the object of safe guarding and improving the wage and employment conditions of its members and to raise members' social status and standards of living in the community (Fajana, 2000). It is an organized association of workers of an industry for the protection of common interests. These interests include: job protection, and maintaining or improving reasonable conditions of work, health and safety, and rates of pay.

\section{THE FUNCTIONS OF TRADE UNION}

Trade union is an outcome of a factory system. It is based on the labour philosophy "United we stand, divided we fall". A trade union functions to achieve its goals in a number of different ways (Fashoyin, 2002; and Ahiauzu, 1984).

a. Trade union must be recognized by its members' employer as an organization with which the employer is prepared to negotiate must recognize a trade union.

b. Functions which are directly concerned with the achievement of the objective of the trade union are:

i. Negotiating with management to improve the level of pay and conditions of work of its members.

ii. Negotiating with management to protect the jobs of its members and to secure a good prospect of a prosperous future for them.

iii. Negotiating to improve physical conditions at work.

c. Other functions according to Purcell, 1998; and Akpala, 1984 which are not directly connected to the achievement of goals are:

i. Lobbying politicians to obtain legislation to improve conditions of work.

ii. Encouraging political and social consciousness amongst members.

iii. Developing political affiliations with other trade unions for achieving political influence over government.

d. A trade union should also provide assistance for individual members who need support. 


\section{The Concept Of Globalization}

Browsing through the plethora of literature that is being churned out from the internet, books, research articles in journals and discussions in the media on the concept of globalization has the tendency not only to mystify it but to obfuscated fact that this process has been happening for ages. Perhaps the most popular idea of globalization is to be found in the notion of a more connected world. Tomlinson (1999:2) maintains that, 'globalization refers to the rapidly developing and ever densening networks of interconnection and interdependencies that characterized modern social life'. Mc Grew $(1992: 65,67)$ not only presents globalization as "simply the intensification of global interconnectedness" but observes that; "Nowadays, goods, capital, people, knowledge, images, pollutants, drugs, fashions, and beliefs rapidly flow across territorial boundaries. Transactional networks, social movements and relationships are extensive in virtually all areas from the academics to the sexual..."

According to Shagari (1997), globalization is a global system running at faster speeds than any in history-the hyper-speed economy. It is characterized by widening and speedy economy; and it is characterized by widening and intensifying linkages in trade and finance. And from institutional perspective, it is defined as the spread of capitalism (Mac Evan, 1990). In other words, it connote "the rapid expansion through giant multinational companies of capitalism and their "blood sapping principles" of "liberalization", "commercialization" "privatization", and "undemocratic and property-based democratization" to several areas of the world including where it had hitherto been resisted or put in check"(Madunagu, 1999:53).

Two main effects follow from these and other similar conceptions of globalization. The first is that globalization is presented as a holistic phenomenon that includes economic, political, legal and socio-cultural dimensions. Moreover the dimensions are closely interconnected that they are difficult, if not impossible to separate.

Globalization becomes a world culture when capitalism becomes the global economic system that structures the actions of states and individuals and provides a common framework for living in the world. Within the parameters of the foregoing, Kavaljit singh (1999) identified five major features of the current globalization process. These are:

a. Rapid growth in international financial transactions

b. Fast growth in trade, especially among multinational corporations(MNCs)

c. Surge in foreign direct investment largely contributed by MNCs.

d. The emergency of global markets

e. And the diffusion of technologies and ideas through rapid expansion of globalized transportation and communication system.

\section{COMPONENTS OF GLOBALIZATION}

Very critical to our understanding of globalization is the dire need to use it as a synonym for the following or which can be regarded as the globalization which generally linked together. These are:

a. Deregulation and liberalization.

b. Privatization and commercialization of public enterprises

c. Foreign Direct Investment (FDI)

\section{THE INSTTUTIONAL AGENTS/DRIVING FORCES OF GLOBALIZATION}

The trend of globalization is currently being pursued with vigours by the now acclaimed instruments or what can be called institutional agents/ forces of globalization which include:

a. International capitalist organizations: the IMF, the World Bank, the World Trade Organization, the London Club, the Paris Club, the G-8, OECD and similar organizations.

b. Large capitalist foundations and institute: the Ford Foundation, the Rockefeller, Westminster Foundations, etc.

c. Multinational Corporations (MNCs): General Motors, Shell, ITT, Julius Bergers, Dumez, Pz industries etc.

Today, as in the past these institutional agents have been the forces in subordinating the economies of the rest of the world; by promoting the precepts, concepts, practices, ideas and ways of seeing capitalist imperialism as the common framework for living in the world.

\section{THE STRATEGIES OF GLOBALIZATION}

Globalizing capitalism has always found it necessary to develop and deploy strategies in its bid for world domination and hegemony. These strategies include:

a. Development in information technology

b. Mergers, strategic alliances and takeovers

c. The attack on the welfare state and public spending 
d. Deregulation and liberalization of international trade

e. The attack on working class ideology and solidarity

f. The debt entrapment of third world economies

g. Democratization

\section{TRADE UNION MOVEMENT IN NIGERIA}

The origin of trade union movement in Nigeria could be traced to the pre- colonial period. At this time, there existed guilds, mutual aid groups and professional or occupational craft unions all of which function to play the role of trade union. However, these associations are not in the modern sense of its full-fledged trade union. Rather, most of them are merely workers association (Otobo, 1987:12). The inception of modern trade unions in Nigeria could be said to coincide with colonialism. Consequently, the first set of trade unions were modeled after British unions. Unlike the situation in most developed countries, trade union preceded industrialization in Nigeria.

The organized trade union movement in Nigeria dates back to 1912 when the workers in the Southern Nigerian Civil Service under the then colonial administration organized themselves into workers representatives. This then became known as the Nigeria Civil Service Union (NCSU) in 1914. This became a pivot with which workers in other sectors began the agitation for the formation of Trade Unions before and after independence in 1960.

At this period, trade union could not take the pattern of radical organization because of the paternalistic nature of colonial government which is the largest employer of public labour. Other unions which emerged during this period were the Nigeria Native Staff Union (NNSU), Nigerian Union of Railway men, Nigerian Mechanics Union and the Nigerian Union of Teachers (NUT). It was in 1938 that the Trade Unions Ordinance was enacted which provided legal backing for trade unions. By 1975 during the military regime of General Murtala Mohammed, Trade Union in the country had risen to over 1,000 which include Mushroom Unions.

In 1976, the Federal Government established a commission of inquiry into the activities of the various unions and appointed an administrator to administer the unions and come up with a structure for the proper administration of the unions. This became necessary as the Unions were polarized into ideological divide which was creating problems in the country. Towards the end of 1977, these Unions were restructured into 42 along industrial line. The government also insisted on the formation of a labour centre as there were various multiple centers. In February 1978, the Nigeria Labour Congress was formed and inaugurated. The then 42 Industrial Unions became affiliates of the Nigeria Labour Congress with a legal backing of Trade Union (Amendment) Decree 22 of 1978.

Several reasons have been given to explain the apparent late arrival of trade unionism in Nigeria.

- Limited wage employment: Since the largest proportions of the citizens are engaged in the informal work sector, the few wage earners are colonial employers and these are restricted to the colonial officers as well as related parastatals.

- Low level of economic activities which limited the recruitment into the formal economy and hence membership of trade union.

- The repressive colonial labour policy also contributed to the late entry of effective trade unionism in Nigeria. The colonial administration regarded trade unions as destabilizing activities. Consequently, it took measures to discourage its employees from membership of these groups.

- Low consciousness of the worker as to the need of unionism.

- Absence of legal backing also impeded the early realization of Trade Union in Nigeria.

However, with time these obstacles were overcome and this paved the way for the emergence of trade unionism in the country. For instance, the emergence of small indigenous and large multi-national companies broke the monopoly of public sector employment in the country. The influence of neighboring countries like Sierra Leone and Ghana also helped to boost the tempo of trade unionism in Nigeria. This factor for instance led to the enactment of Trade Union Ordinance in 1938 which gave legal backing to trade unions in the country.

The Second World War also played important role in the growth of trade union in Nigeria. The war brought untold hardship to the workers and the general public in form of acute shortage of essential commodities, rise in prices, stagnant wage structure (Otobo 1987:21). These problems pushed many workers into joining trade unions which was seen as the only forum for improving their bad economic condition. Union agitation during the period led to the introduction of Cost Of Living Allowance (COLA) as well as the first general strike in the country in 1945 with the participation of about 42,000 workers (Fajana, 1995:146). The war heightened the socio-political consciousness of the workers.

The Nigeria Labour Congress [NLC] was formally constituted as the only national federation of trade unions in the country in 1978. Before then, four labour centres existed. These are Nigeria Trade Union Congress [NTUC], Labour Unity Front [LUF], United Labour Congress [ULC] and Nigeria Workers Council [NWC]. The 
emergence of the NLC ended decades of rivalry and rancor involving the four centres and unions affiliated to them. The unions, numbering over 1,000 were also restructured into 42 industrial unions.

The organization has had a chequered history, surviving two instances of dissolution of its national organs and consequent appointment of state administrators. The first was in 1988 under the military regime of General Ibrahim Babangida. Congress' opposition to the anti-people Structural Adjustment Programme incensed the military administration to take over the NLC. The second military intervention was in 1994 during the regime of General Sani Abacha, whose government also became fed up with the labour movement's agitation for the restoration of democracy. Like the initial case, the military government dissolved NLC's National Executive Council and appointed a Sole Administrator. The same treatment was meted to the two unions in the oil and gas industry National Union of Petroleum and Natural Gas Workers [NUPENG] and Petroleum and Natural Gas Senior Staff Association of Nigeria [PENGASSAN]. However, the administrators apparently added a further brief which plundered the finances of Congress and the two unions.

The dissolution exemplified the travails of Congress, its leadership, affiliates and state councils, under military rule. Arbitration, prolonged and unlawful detention of labour leaders, invasion and disruption of union meetings, seminars and other activities of Congress and its components by security forces and a vicious antilabour campaign by the state generally marked the period. The military also invoked its legislative prerogatives to unleash all manner of legislation to check the activities of unions. For instance, under General Abacha, a decree that banned a section of the movement from holding leadership position in Congress came into effect. However, with the death of General Abacha, the unions reclaimed Congress, culminating in a National Delegates Conference held on January 29, 1999. The leadership led the NLC from 1999 - February 2007 with another delegate conference was held on February 2007, the current leadership was elected - Abdulwahed Ibrahim Omar - President

\section{THEORETICAL FRAMEWORK}

At the core of social sciences research lays the imperative to provide a framework on which a research is based. This framework consists in the theoretical approach. The framework appropriate for an in-depth study for the purpose of clear understanding of this study is the Marxist approach. Thus, the Marxist theory as presented by the Karl Marx is hereby adopted.

\section{MARXIST APPROACH}

Karl Marx (1818-1883) was in many respects the most influential political theorist of the 19th century. He sought to combine factual analysis and political prescription in a thorough survey of the modern economic system. Ageing that, "the history of all hitherto existing society is the history of the class struggles," and that liberal governments and ideology were merely agents of the exploiting owners of property. Marx advocated the abolition of private property and predicted the demise of capitalization after a sense if receiving crises. The abolition of property and therefore of class exploitation would make possible a situation in which individual will contribute according to their abilities and take according to their needs. The state, following a transitional period in which the working class would rule, would eventually wither away.

The Marxist approach emphasize a materialistic interpretation of history, a dialectical method of analysis, a critical stance toward existing social arrangement, and a political program of revolution. Marx maintained that everything of value in society results from human labour. Thus, working men and women as engaged in making society, in creating the conditions for their own existence.

Marx viewed the exploitative economic arrangements of capitalism as the reason for making conflict in form of revolution inevitable, which will usher in a classless society.

The situation in Nigeria could be linked to this framework, as workers under the umbrella of NLC are confronted with imperialist policies which strengthen capitalism and exacerbate distributional inequalities, unemployment, poor working conditions, and reduction in welfare of workers. Thus the government and agents of capitalism are insensitive to their which will result to revolution.

\section{Discussion Of Issues}

Trade unions are often in contestation with the spirit of capitalism currently globalized in the form of market economy. The implementation of neo-liberal policies of privatization of state companies, commercialization of social services and deregulation of economy have combined to aggravate the socioeconomic crises and other monumental problems. There are consequences and challenges for the trade union movement in Nigeria that result from the various strategies that are applied for driving globalization.

The application of IT solutions radically redefines the nature of the workplace, the nature of work and the relationship that people form at work. It enables home-based work, this means that the original definition of the workplace as an office in which workers interact and can therefore be organized is changing. The nature of work is also affected. IT redefines the traditional distinction between white-collar and blue-collar workers. It 
also redefines the work that people, especially managers perform. Unlike in the past when word processing was considered to be a secretarial function. IT now places it within the ambit of the managerial job. All categories of employees are thus required to acquire new skills and enter into new forms of work relationships.

Information technology also redefines the conception of time and deadlines. It demands that work assignments be completed within shorter periods of time, that work be performed at all times and that deadlines be readjusted accordingly. IT leads to skills obsolescence and deskilling of employees, and work simplification which ease the replacement of workers.

Jenkins (1987) has noted that the internationalization of capital renders national trade unions subject to blackmail, weakens the effectiveness of the threat to strike and places trade unions in subsidiaries at a great disadvantage in union-management negotiations.

Another strategic implication for trade union is the need for adjustments in the new organizations following the merger, strategic alliance or takeover. These adjustments usually include restructuring and often lead to massive lay-offs either directly or through early retirement for various categories of employees. The merger and acquisition also require that the unions to merge and restructure which often lead to conflict between different groups of workers; such conflict usually weakens solidarity among the workers as a group and in the trade union organization.

Liberalization and deregulations also have major consequences for trade unions. The liberalization of the textile and clothing trade following the Uruguay Round of agreements impacted negatively on the Nigerian textile industries. According to Iyayi (2001:420) as at June 2001, the industry had experienced the closure of several textile plants led to job lost among workers. Also World Bank and IMF programs of privatization of state-owned enterprises and cut in public spending via monetization policy has also occasioned massive job losses and reduction in the membership of trade union in Nigeria.

Privatization, commercialization and deregulation policies are based on capitalist value, ideology, and assumptions; such capitalist ideology de-emphasizes the role of labour in production. It treats labour as merely one of the factors of production employed by capitalists and which, like other factors, can be expanded or contracted as the case may be, in order to increase productivity (Nnoli, 1999).

Institutional agents of globalization sponsored managerial solutions which led to new human resources managements. They have introduced the concepts of re-engineering, subcontracting, contract labour, outsourcing and various other forms of precarious employment as the new tools for reducing costs and managing human resources. In essence, casualization of labour is achieved which increased insecurity in the employment relationship and forcing massive employees into early retirement. These developments have serious implications for the memberships of trade unions because causal staff are not define within the membership of trade unions and the base of the junior staff unions is being eroded; all these weaken the potential of the trade union movement for radical action.

With the advent of globalization, there had been a decrease of trade union density, increase of the informal sector (most of the workers employed in the informal sector are women and children), increase of atypical forms of labour (contract labour), global attack against workers' rights, strikes repressed by employers or the police, trade unionists harassed, arrested, detained, killed or "disappeared" . some employee were dismissed because of their trade union activities, unequal pay where women are paid anything less than men for doing similar job or different job of equal value while numerous women and children becomes victims of crossborder human trafficking, and fundamental human rights compromised.

Globalization enhanced economic inequalities and produced social polarization. Hence, succession to wealth and poverty tend to become hereditary within particular social groups. Thus, the line which distinguishes the 'haves' and 'have not' will further thickened as the pattern of shares acquisition might succeed in transforming the bulk of the acquired shares into the hands of a few rather than the hands of the generality of the people.

On the political aspect, of privatization, Onimode (1988), argued that privatization is a class-inspired and partisan policy designed for the regressive distribution of wealth, income and power. According to him, privatization aggravates an already skewed distribution in favour of the rich and powerful, which have been undermining the public enterprises in Nigeria.

The foreign exchange crisis generated particularly by currency devaluation led to de-industrializationthe collapse of import substitution in the Nigerian economy. The effects were massive retrenchment of workers, adverse labour market conditions due to high unemployment and job insecurity, reduction in union membership and union density, reduced union funds, lethargy for unionism due to tight labour market and wide spread job insecurity (Onimode, 1991; Otobo, 1992; and Onyeonoru, 1994).

Another negative effect of globalization policies is the erosion of industrial democracy. By industrial democracy, it means the involvement of workers in decision making process... (Ezeani,1995:169). And the overall objective of industrial democracy is therefore, to ensure effective participation in decision making within the work arena by all who have interests in it. Regrettably, the current neo-liberal policies of privatization and 
commercialization are gradually delivery a blow to industrial democracy. This is primarily because, workers participation in decision making is confined to the public sector in Nigeria like almost all African countries. As a result, once the public enterprise is privatized, workers representatives can no longer sit on the board or any other participatory structure; only the shareholders are entitled to sit on the participatory structure.

There is also lowering wages, especially where the level of normal wages is eroded by inflation, as most African countries like Nigeria now experiences an unprecedented hyper inflationary trend. Workers are hard hit by the economic policies in the context of globalization. With very low or static salaries and delay in payment of salaries, most workers cannot afford to build houses or own cars; even some cannot afford to pay their children's school fees and medical bills. This is because their salaries are not equivalent to their purchasing power and rendered worthless by the hyper inflationary and skyrocketing prices of goods and services, and the resultant high cost of living; and this reinforced Castro's assertion (2002) that, the number of people living in extreme poverty has significantly increased everywhere under globalization. In all, therefore, an expected result of globalization is the trimming of the workforce, loss of welfare by workers (Galal et al, 1994). And led to decline in their wellbeing, comfort and happiness, as the workers are still walloping and galloping in poverty and are surviving on deficit through loans and over draft.

Finally, it is evident that globalization policies has failed to promote workers' social welfare, as it led to elimination of government's involvement in direct service provision, as it withdraws from social provisioning and supporting, and commodification of basic services rendered by the government, this tend to create and consolidate inequality in the society, as the government shifts its functions, activities and responsibilities to private sector which promotes and deepens capitalism in Nigeria.

\section{Conclution}

In a point of history, the phenomenon of globalization is not natural nor divine but consciously driven and coordinated by forces. It is global and dominant in the world today which was created by the dominant social forces to serve the specific interests. It is a process of expanding capitalist economic practices to the rest of the world on terms and conditions arranged by and favorable to leading capitalist countries, organizations, institutions and individuals capitalists. The strategies developed by globalizing capitalism have and are producing major consequences for trade unions in Nigeria. Therefore, the working class who are negatively affected by neo-liberal globalization policies cannot fold arms and watch globalization roll over them like tsunami, the repressive nature of the neo-liberal reforms notwithstanding. As such to answer the clarion call of Karl Marx that "Workers of the world unite; you have nothing to lose but your chains" (1884), to meet these new challenges posed by globalization, trade unions in Nigeria must alter their current framework; which must involve:

- Paying attention to the political education of union members

- Strengthening internal democracy in the management of the unions

- Professionalism of union work

- Entering into strategic alliances

- Political engagement on the part of the movement as a whole

On consideration, it is only by pursuing these and related actions that trade union movement in Nigeria and elsewhere can remain relevant and effective in the new world of globalizing capitalism.

\section{Bibliography}

[1]. Adewumi, F. (2007). Unity and division: the dialectics of the Nigerian trade union Movement. Kaduna:

[2]. Akinyanju, P. "Trade Unions and Democratic Struggle" in CDHR Nigeria, Non-Governmental organization and Democracy: Lagos CDHR 1997: 65-88.

[3]. Akpala, A. (1982) Industrial relations model for developing countries. The Nigerian System, Enugu: Fourth Dimension Printers.

[4]. Davison, R.B. (1977), Industrial Relations Decree in Nigeria. Zaria: Ahmadu Bello University Press.

[5]. Ezeani, E. O. (1995), "Industrial Democracy in Developing Countries: A theoretical and empirical analysis" In Nigeria Journal of Public Administration and Local government, Vol. 6, No. 1

[6]. Fajana, S. (2000) Functioning of the Nigerian Labour Market. Lagos: Labofin and Co.

[7]. Fajana, S. (2002) Industrial Relations in Nigeria. Theory and features. Lagos: Labofin and Co.

[8]. Fashoyin, T. (2007), Industrial Relations in Nigeria: Development and Practice (2 ${ }^{\text {nd }}$ ed.). Longman.

[9]. Iyayi, F (2001) "Globalization and trade union in Nigeria" in The Nigerian journal of Economics and Social Sciences (Nov), Vol. 43.No. 3

[10]. Jenkins, R. (1987), Transnational Corporations and Uneven Development: The internationalization of capital and the Third World. London: Routledge.

[11]. Madunagu, E. "Globalization and its victims" The Guardian, July 26, 1999:53

[12]. Marx, k. and Engels, F (1967, first published in 1848) "Manifesto of Communist Party" in Marx, k. and Engels, F, selected works, vol. 1, Foreign Languages Publishing House, Moscow.

[13]. McGrew, A. (1992), “A Global Society” in Hall, S., Held, D. and McGrew, (eds), Modernity and its Future. Cambridge: Polity Press

[14]. Nnoli, O. (1999), "Foreword” in Obasi, I. N. State-Labour Relations under SAP, Nigeria. Ibadan: Sam Bookman Publishers 
[15]. Onimode, B. (1988), “The Political Economy of Privatization in a Depressed Economy”, Paper presented at the Nigerian Economic Society (NES) Seminar on Privatization of Public Enterprises in Nigeria

[16]. Onyeonoru, I. P. (1994), "Labour Migration and Rural transformation in Nigeria". In Journal of International Sociology, Vol. 9, No. 2,(June) 2004

[17]. Otobo, D. (1987) The Role of Trade unions in Nigerian Industrial Relations. Lagos: Malthouse Press

[18]. Otobo, D. (1992), "Organized Labour and Structural Adjustment Policies in Nigeria" In Otobo, D. (ed) Further Readings in Nigerian Industrial Relations. Ibadan: Malthouse Press

[19]. Otobo, D. (2000), Industrial Relations: Theory and Controversies. Lagos: Malthouse Press Shagari, A. (2003),“Globalization and Cultural Pluralism: consequences and changes for Africa”. In Globalization in Nigeria, book of reading No. 1, Fullbright Alumin (nigeria), Tomlinson, J.(1999), Globalization and Culture. Cambridge: The University of Chicago press.

[20]. Webb, S. and Webb, B. (1920) Industrial Democracy, London: Longman 